\title{
Assessment of Tree Species Diversity in the University of Lagos, Akoka, Lagos \\ ${ }^{1}$ OGUNYEBI, AL; ${ }^{1}$ ABIODUN, MJ; ${ }^{1}$ OLUDOYE, OO; ${ }^{1}$ OMOYAJOWO, KO; ${ }^{2}$ FAYENUWO, GA; ${ }^{*}$ FINGESI, TS
}

\author{
${ }^{1}$ Environmental Biology Laboratory, Department of Cell Biology and Genetics, University of Lagos, Akoka, Lagos, Nigeria \\ ${ }^{2}$ Department of Agriculture, Wesley University Ondo, Ondo State, Nigeria \\ E-mail: *justinafingesi@yahoo.com
}

\begin{abstract}
This study was aimed at assessing and providing management options for tree species growing on Akoka Campus of University of Lagos, Southern-Western Nigeria by collecting data from four (4) randomly selected $50 \mathrm{~m} \times 50 \mathrm{~m}$ plots in the study area. The assessment was carried out through extensive field survey with the inventory of all tree species, including their mean diameters at breast height $(\mathrm{DBH})$, heights $(\mathrm{H})$. A total of 67 woody tree species within 27 families were represented in the study area. The family Fabaceae had the highest frequency (14 species) representing $20.59 \%$ of total species enumerated in all the plots followed by Moraceae which consists of 7 species $(10.29 \%)$. The result revealed high values for tree species diversity and also provided necessary information such as tree height and diameter at breast height, which will be used in proper management and maintenance of the tree species numbered; hence, proper management and sustainability of the tree species can be achieved.
\end{abstract}

\section{DOI: https://dx.doi.org/10.4314/jasem.v22i1.3}

Copyright: Copyright $\odot 2017$ Ogunyebi et al. This is an open access article distributed under the Creative Commons Attribution License (CCL), which permits unrestricted use, distribution, and reproduction in any medium, provided the original work is properly cited

Dates: Received 11 November 2017; received in revised form 14 December 2017; accepted 30 December 2017

Keywords: Breast height, Fabaceae, Moraceae, Management, Sustainability.

Nigeria vegetation is one of the most endowed in Africa, as almost all the vegetation types that exists in other African countries are found widely distributed in different geopolitical zones of the country, this is favoured by the variations in climate and geographic features, which harbours about 7895 species of plant; this makes her one of the richest countries in the continent in terms of biodiversity Adeyemi and Ogundipe, 2012; Pelemo et al., (2011).

However, these habitats are under threat from advancing civilization and other unsustainable human activities, the attitude of the populace towards conservation is relatively poor; thereby resulting to inevitable loss of genetic resources at all levels. Ideally, conservation of biodiversity is supposed to be an intrinsic responsibility for all mankind according to IUCN, but this is far from the case, as the rate of destructive anthropogenic activities on the floras and biodiversity at large escalates daily with nearly $90 \%$ of forest in Nigeria cleared (Kabiru, 2008). In 2010 Nigeria had 9 million hectares of forest, 336,000 hectares of which were primary forest (FAO, 2010). But the continual existence of this forest is in doubt, as several authors such as Batta et al., 2013; Pelemo et al., 2011; Ladipo (2010), have lamented the rate of deforestation in the country which is estimated at $3.5 \%$ per year, translating to a loss of 350,000 400,000 ha of forest land per year and the entire Nigeria's forest land area now is about $10 \%$, which is well below FAO's recommended national minimum of $25 \%$. Perhaps this is threatening about 484 plant species in 112 families of 7895 plant species estimated in the country with extinction (Pelemo et al., 2011). Unarguably, one of the persistent problems associated with deforestation is the selective exploitation of some targeted species for economic, social and spiritual paraphernalia, and trees are mostly targeted (Alamu and Agbeja, 2011).

In Nigeria, there are about 560 species of trees (Ihenyen et al., 2009). However continued existence of these trees species is in jeopardy; because deforestation, logging and other various forms of unsustainable activities have drastically increased in recent times, thereby posing appreciable risk of local extinction to some species. Indeed, the tree species growing in this study area, situated in the most commercial and urbanized city of Nigeria and accommodates about $10 \%$ of the entire population of the country (Pelemo et al., 2011), are however not spared from the aforementioned threats. Rapid increase in population has led to the development of several infrastructural facilities so as to provide comfort to insatiable human's wants; which of course has led to direct and indirect destruction of almost all the ancestral vegetation in and within the study area and its proximate vegetation. Urbanization and other commercial activities are socioeconomic problems, and are too difficult to be controlled. Attempt to list the tree species that exist in this area has been made, but only skeletal attempt has been made so far Shonubi and Okusanya, 2007; Adekanmbi and Ogundipe (2009). This research is aimed at 
enumerating and identifying different tree species in each sampling point pertaining to the study in order to provide a detailed assessment of the remnant plants species, so as to decide on adequate management options and conservation measures for sustainability.

\section{MATERIALS AND METHODS}

Study Area: The study was conducted in Akoka campus of University of Lagos, Yaba, Lagos, SouthWestern Nigeria (Fig. 1). The area which is largely surrounded by the scenic view of the Lagos lagoon comprises a total of 802 acres $\left(3.25 \mathrm{~km}^{2}\right)$ of land. It is located on longitude $3^{\circ} 24^{\prime} \mathrm{E}$ and latitude $6^{\circ} 30^{\prime} \mathrm{N}$ and on elevation of $40-90 \mathrm{~m}$, which makes flooding difficult.

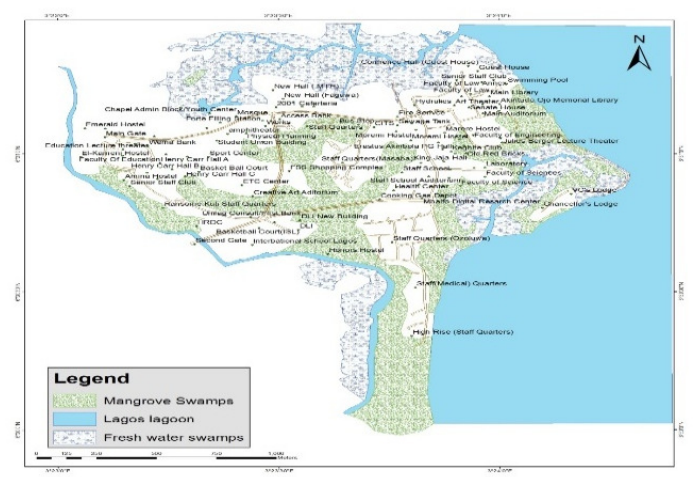

Fig 1: Map showing study area; fresh and mangrove swamp of University of Lagos

The vegetation in this area is half cleared and developed, and the remainder is represented by mangrove vegetation and most of the species have diminished in number and density (Nodza et al., 2014). It has an undulating terrain, half of which represents buildings, with various fresh water channels and creeks passing across at different location of this area. A large area of mangrove swamps, roughly $50 \%$, dominates the vegetation. In the north and southeast lies the brackish lagoon water which supports a typical terrestrial habitat, and experiences less human disturbance while in the south and southwest lays the fresh water, where the soil is highly rich and supports a rich flora which is highly favoured by the climate type much disturbed by human activities. A rich lush of grasses species such as Panicum subalbidum, Panicum maximum, Andropogon spp, Sporobolus spp, Andropogon spp; herbaceous plants such as Chromolaena odorata, Ipomoea aquatic, Combretum spp, Asystasia gangentica, Typha australis, and Sedges dominated by Kyllinga erecta, Cyperus esculentus and Cyperus javanicus, amongst others, were well represented in each sampling plot.

Data Collection: A Global Position System (GPS) was used during the sampling period. The study area was divided into four sampling plots. In each of the sampling plot, trees were enumerated in a $50 \times 50 \mathrm{~m}$ plot, samples were collected and the tree species enumerated were identified.

The heights of the various tree species encountered were measured using Haga Altimeter and diameter at breast height $(\mathrm{DBH})$ was taken using a Diameter Tape at 1.3 meters above the ground level.

Haga Altimeter was used to measure the tree heights within a fixed distance to the tree by the trigonometric principle and slope in percentage. A suitable scale was selected by rotating the adjustment disk at the front of the device and a reference tape was installed at the tree to determine the distance optically. Consequently, the following measurements were taken; (i). The corresponding height scale was selected turning the adjustment disk; in this case $15 \mathrm{~m}$ scale was used (i.e. standing at $15 \mathrm{~m}$ away from the tree to be measured). (ii). the bottom of the tree was sighted through the Haga Altimeter and then locked (the pointer needle) for the value gotten to be recorded. The same procedure was carried out for the crown of the tree. (iii). the difference between the value obtained for the crown of the tree and that of the bottom of the tree was calculated to determine the tree height.

Diameter Tape (D-TAPE): A diameter tape (D-tape) was used to measure diameter of the trees at breast height $(\mathrm{DBH})$. The $\mathrm{DBH}$ was measured at a fixed height of $1.3 \mathrm{~m}(130 \mathrm{~cm})$ above the ground level. The DBH was measured up high the tree (at $1.3 \mathrm{~m}$ ) to avoid measuring a tree's butt swell. Thus the height and diameter values were used to determine the volume of the trees.

Determination of $\mathrm{DBH}$ : The diameter at breast height of the trees was determined using a Diameter Tape to take the diameter of the trees at 1.3 meters above ground level.

Data Analysis: The data were analysed using the Shannon-Wiener diversity index. The ShannonWiener Diversity Index, which accounts for species richness and how the species are distributed, is derived from the relation;

$\mathrm{R}$

$H^{\prime}=-\Sigma \rho i \cdot \operatorname{In}(\rho i)$

$i=1$

Where: $H^{\prime}=$ Shannon-Weiner index; $\mathrm{R}=$ Number of species; $\rho i=$ Proportion of individuals or abundance of the $i^{\text {th }}$ species expressed as a proportion of the total number of individuals of all species $($ In $=\log$ base10).

Also, the mean of the diameters at breast height (DBH) and total height of the different species of trees were taken. The analysis of the frequency of the individual families was done by plotting a chart of the 
frequency of each family against the total number of families encountered in the study area.

\section{RESULTS AND DISCUSSIONS}

A total of 67 woody tree species with varying heights and diameter at breast height (all belonging to 57 genera and 26 families) were enumerated (Table 1). The number of tree species encountered in a sample survey was adopted as a surrogate for the actual species richness in this study (Adekunle et al., 2013).
Among 26 families identified, Fabaceae (20.89\%) and Moraceae (10.45\%) were the most frequent species (tables 2 and 3). Several families namely: Avicennaceae, Sapindaceae, Calophyllaceae, Casuarinaceae, Chrysophylloideae, Boraginaceae, Malvaceae, Meliaceae, Lythraceae, Lauraceae, Verbenaceae were the least frequent tree species, each occurring in only one or two belt transect.

\begin{tabular}{|c|c|c|c|c|}
\hline $\mathbf{S} / \mathbf{N}$ & Scientific Name & Local Name & DBH $(\mathbf{c m})$ & Height (m) \\
\hline 1. & Adansonia digitata & Baobab tree (ose) & 101 & 15 \\
\hline 2. & Albizzia lebbeck & Eshegeshege, gbagbo & 32 & 14 \\
\hline 3. & Albizia zygia & Nyie avu, Ayin rela & 48 & 20 \\
\hline 4. & Alstonia boonei & Igi ope, Nkwu, kwakwar & 44 & 13 \\
\hline 5. & Anacardium occidentale & Cashew nut,Kaju,Kasu & 28 & 9 \\
\hline 6. & Annona muricata & Soursop, Eko oyinbo & 25 & 8 \\
\hline 7. & Anthocleista djalonensis & Ayuu,Sapo & 38 & 12 \\
\hline 8. & Anthocleista vogelii & Cabbage tree, Mpoto, Apa oro & 27 & 15 \\
\hline 9. & Artocarpus communis & Jackfruit tree & 59 & 15 \\
\hline 10. & Avicennia germinans & Black mangrove & 49 & 12 \\
\hline 11. & Azadirachta indica & Neem tree, Dongoyaro & 43 & 8 \\
\hline 12. & Bauhinia monandra & Orchid tree & 47 & 7 \\
\hline 13. & Blighia sapida & Ackee, Bread fruit & 57 & 13 \\
\hline 14. & Bombax buonopozense & Eso & 62 & 23 \\
\hline 15. & Bridelia micrantha & Coast goldleaf & 41 & 15 \\
\hline 16. & Calophyllum inophyllum & Borneo Mahogany, Alexandrian laurel & 38 & 13 \\
\hline 17. & Cassia siamea & Pheasant wood & 28 & 7 \\
\hline 18. & Casuarina equisetifolia & Coast sheoak & 43 & 12 \\
\hline 19. & Ceiba pentandra & Kapok tree, silk-cotton tree & 35 & 24 \\
\hline 20. & Chrysophyllum albidum & Agbalumo tree & 30 & 6 \\
\hline 21. & Citrus sinensis & Sweet orange, osan & 39 & 8 \\
\hline 22. & Cocos nucifera & Coconut, agbon & 24 & 13 \\
\hline 23. & Cola gigantean & Giant cola & 50 & 26 \\
\hline 24. & Cola nitida & Kola nut, Abata cola, goro cola & 46 & 13 \\
\hline 25. & Cordia abyssinica & Kababu, mukumari & 42 & 8 \\
\hline 26. & Delonix regia & Flame tree, royal Poinciana & 34 & 9 \\
\hline 27. & Dialium guineensis & Awin, icheku & 44 & 8 \\
\hline 28. & Elaeis guineensis & African oil palm & 43 & 10 \\
\hline 29. & Erythrina senegalensis & Nte/Coral tree & 41 & 8 \\
\hline 30. & Eugenia malaccensis & Malaysian apple & 15 & 12 \\
\hline 31. & Ficus congoensis & Clusterfig & 41 & 9 \\
\hline 32. & Ficus exasperate & Sycamore fig & 48 & 16 \\
\hline 33. & Ficus sycomorus & Fig tree & 41 & 18 \\
\hline 34. & Ficus vallis-chaudae & & 40 & 10 \\
\hline 35. & Gliricidia sepium & Agunmaniye & 47 & 11 \\
\hline 36. & Gmelina arborea & Beechwood, gamhar & 38 & 20 \\
\hline 37. & Holarrhena floribunda & False rubber tree & 33 & 22 \\
\hline 38. & Hildagardia barteri & Okurugbedu & 93 & 12 \\
\hline 39. & Hura crepitans & Sandbox tree, jabillo, possum wood & 55 & 12 \\
\hline 40. & Jacaranda mimosifolia & Brazilian rose tree, blue trumpet tree & 52 & 13 \\
\hline 41. & Khaya grandifoliola & African mahogany & 95 & 38 \\
\hline 42. & Lagerstroemia speciosa & Pride of India, banaba & 40 & 27 \\
\hline 43. & Mangifera indica & Mango tree & 44 & 9 \\
\hline 44. & Milicia excels & Iroko, African teak & 71 & 40 \\
\hline 45. & Millettia thonningii & Teteku & 36 & 5 \\
\hline 46. & Morinda lucida & Oruwo, eze-ogu & 37 & 8 \\
\hline 47. & Newbouldia laevis & African boarder tree & 32 & 8 \\
\hline 48. & $\begin{array}{l}\text { Peltophorum } \\
\text { pterocarpum }\end{array}$ & Copperpod, golden flamboyant & 43 & 7 \\
\hline 49. & Persea Americana & Avocado tree & 32 & 12 \\
\hline 50. & Phoenix reclinata & African wild date palm & 37 & 8 \\
\hline 51. & Pithecellobium dulce & Manila Tamarind & 48 & 12 \\
\hline 52. & Psidium guajava & Guava tree & 31 & 5 \\
\hline 53. & Raphia hookeri & Raphia palm, Ogoro, ayon udin & 45 & 7 \\
\hline 54. & Rauvolfia vomitoria & Swizzle stick, Asofeyeje, & 48 & 7 \\
\hline 55. & Roystonea oleracea & Royal palm & 51 & 11 \\
\hline 56. & Senna alata & Candle bush, ringworm shrub & 32 & 8 \\
\hline 57. & Senna fistula & Alexandrian Senna & 27 & 7 \\
\hline 58. & Spondias mombin & Hog plum & 35 & 13 \\
\hline 59. & Sterculia tragacantha & Owun, Omurin & 40 & 9 \\
\hline 60. & Tabebuia rosea & Pink trumpet tree & 42 & 10 \\
\hline 61. & Tectona grandis & Indian Oak & 37 & 12 \\
\hline 62. & Terminalia catappa & Almond tree & 32 & 11 \\
\hline 63. & Terminalia randii & Spiny cluster leaf tree & 19 & 7 \\
\hline 64. & Terminalia ivorensis & Idigbo, Afara & 18 & 6 \\
\hline 65. & Terminalia superba & Afara, limba & 52 & 17 \\
\hline 66. & Treculia Africana & African breadfruit, Ukwa & 43 & 12 \\
\hline 67. & Polyalthia longifolia & Ashok tree, Indian mast tree & 17 & 8 \\
\hline
\end{tabular}




\begin{tabular}{|c|c|c|}
\hline $\mathbf{S} / \mathbf{N}$ & Scientific Name & Family \\
\hline 1. & Adansonia digitata & Bombacaceae \\
\hline 2. & Albizzia lebbeck & Fabaceae \\
\hline 3. & Albizia zygia & Fabaceae \\
\hline 4. & Alstonia boonei & Apocynaceae \\
\hline 5. & Anacardium occidentale & Anacardiaceae \\
\hline 6. & Annona muricata & Annonaceae \\
\hline 7. & Anthocleista djalonensis & Loganiaceae \\
\hline 8. & Anthocleista vogelii & Loganiaceae \\
\hline 9. & Artocarpus communis & Moraceae \\
\hline 10. & Avicennia germinans & Avicennaceae \\
\hline 11. & Azadirachta indica & Fabaceae \\
\hline 12. & Bauhinia monandra & Fabaceae \\
\hline 13. & Blighia sapida & Sapindaceae \\
\hline 14. & Bombax buonopozense & Bombacaceae \\
\hline 15. & Bridelia micrantha & Euphorbiaceae \\
\hline 16. & Calophyllum inophyllum & Calophyllaceae \\
\hline 17. & Cassia siamea & Fabaceae \\
\hline 18. & Casuarina equisetifolia & Casuarinaceae \\
\hline 19. & Ceiba pentandra & Bombacaceae \\
\hline 20. & Chrysophyllum albidum & Chrysophylloideae \\
\hline 21. & Citrus sinensis & Rubiaceae \\
\hline 22. & Cocos nucifera & Arecaceae \\
\hline 23. & Cola gigantean & Sterculiaceae \\
\hline 24. & Cola nitida & Sterculiaceae \\
\hline 25. & Cordia abyssinica & Boraginaceae \\
\hline 26. & Delonix regia & Fabaceae \\
\hline 27. & Dialium guineensis & Fabaceae \\
\hline 28. & Elaeis guineensis & Arecaceae \\
\hline 29. & Erythrina senegalensis & Fabaceae \\
\hline 30. & Eugenia malaccensis & Myrtaceae \\
\hline 31. & Ficus congoensis & Moraceae \\
\hline 32. & Ficus exasperate & Moraceae \\
\hline 33. & Ficus sycomorus & Moraceae \\
\hline 34. & Ficus vallis-chaudae & Moraceae \\
\hline 35. & Gliricidia sepium & Fabaceae \\
\hline 36. & Gmelina arborea & Anacardiaceae \\
\hline 37. & Holarrhena floribunda & Apocynaceae \\
\hline 38. & Hildagardia barteri & Malvaceae \\
\hline 39. & Hura crepitans & Euphorbiaceae \\
\hline 40. & Jacaranda mimosifolia & Bignonaceae \\
\hline 41. & Khaya grandifoliola & Meliaceae \\
\hline 42. & Lagerstroemia speciosa & Lythraceae \\
\hline 43. & Mangifera indica & Anacardiaceae \\
\hline 44. & Milicia excels & Moraceae \\
\hline 45. & Millettia thonningii & Fabaceae \\
\hline 46. & Morinda lucida & Rubiaceae \\
\hline 47. & Newbouldia laevis & Bignonaceae \\
\hline 48. & Peltophorum pterocarpum & Fabaceae \\
\hline 49. & Persea Americana & Lauraceae \\
\hline 50. & Phoenix reclinata & Arecaceae \\
\hline 51. & Pithecelobium dulce & Fabaceae \\
\hline 52. & Psidium guajava & Myrtaceae \\
\hline 53. & Raphia hookeri & Arecaceae \\
\hline 54. & Rauvolfia vomitoria & Apocynaceae \\
\hline 55. & Roystonea oleraceae & Arecaceae \\
\hline 56. & Senna alata & Fabaceae \\
\hline 57. & Senna fistula & Fabaceae \\
\hline 58. & Spondias mombin & Anacardiaceae \\
\hline 59. & Sterculia tragacantha & Sterculiaceae \\
\hline 60. & Tabebuia rosea & Bignonaceae \\
\hline 61. & Tectona grandis & Verbanaceae \\
\hline 62. & Terminalia catappa & Combretaceae \\
\hline 63. & Terminalia randii & Combretaceae \\
\hline 64. & Terminalia ivorensis & Combretaceae \\
\hline 65. & Terminalia superba & Combretaceae \\
\hline 66. & Treculia Africana & Moraceae \\
\hline 67. & Polyalthia longifolia & Annonaceae \\
\hline
\end{tabular}

The low annual precipitation rate and climate of the study area may have contributed to average tree growth rates and low to medium tree basal area. The diversity index $\left(H^{\prime}\right)$ for the tree species was calculated to be 4.204 , for all the species enumerated, and this is high, representing a diverse and equally distributed community. Thus this statistics also illustrate the great numbers of exotic plants that have become established in native habitats (Nodza et al., 2014).

\begin{tabular}{cll}
\multicolumn{3}{c}{ Table 3: Frequency of each family enumerated in the study area } \\
\hline S/N & Family & Frequency $\mathbf{( \% )}$ \\
\hline 1. & Bombacaceae & 4.48 \\
2. & Fabaceae & 20.89 \\
3. & Apocynaceae & 4.48 \\
4. & Anacardiaceae & 5.97 \\
5. & Annonaceae & 2.99 \\
6. & Loganiaceae & 2.99 \\
7. & Moraceae & 10.45 \\
8. & Avicennaceae & 1.49 \\
9. & Sapindaceae & 1.49 \\
10. & Euphorbiaceae & 2.99 \\
11. & Calophyllaceae & 1.49 \\
12. & Casuarinaceae & 1.49 \\
13. & Chrysophylloideae & 1.49 \\
14. & Rubiaceae & 2.99 \\
15. & Arecaceae & 7.46 \\
16. & Sterculiaceae & 2.99 \\
17. & Boraginaceae & 1.49 \\
18. & Myrtaceae & 2.99 \\
19. & Malvaceae & 1.49 \\
20. & Bignonaceae & 4.48 \\
21. & Meliaceae & 1.49 \\
22. & Lythraceae & 1.49 \\
23. & Lauraceae & 1.49 \\
24. & Verbenaceae & 1.49 \\
25. & Combretaceae & 5.97 \\
26. & Rutaceae & 1.49 \\
\hline
\end{tabular}

In order to measure the tree species diversity of a forest, there is need to know the total area of the forest and the area occupied by each species, this information was made available from the inventory data and the actual survey carried out (Fig. 2). The study provides a baseline for the management of protected areas in developing countries and it shows the potential of in situ method in conservation. Forest habitats play a central role in the functioning of the biosphere, as they are the origin of many cultivated plants and animals.

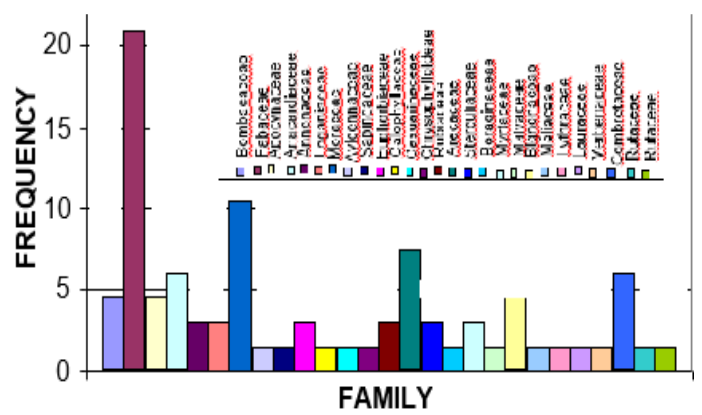

Fig 2: Families of Tree Species and the Frequency at which they occur within the Study Area

To examine the efficacy of nature reserves as a means of biodiversity conservation, ecologist can use such information from this study on rare and common tree species alike to help manage habitat as well as provide cultural resource values of these trees; the qualitative characters related with density, dominance and diversity of these trees could well act as indicators of changes and susceptibility to anthropogenic stressors among various vegetation 
categories and their formations, which could be further interpreted as distinct flora habitats.

The frequency distribution of tree species suggested that most of them had low frequency as would be expected of typical species-abundance distributions. Tree structure and diversity could play an important role in climate regulation as both could influence forest biomass production and hence determine the forest' capacity for carbon storage. Findings in this study could help rationalize the need for an ecologically sound fallow period; this will ensure renewal of at least some tree species and some fauna habitat element (Kumar et al., 2006).

During the survey, it was observed that some trees needed to be pruned because they posed potential risk/threat to the people and properties on the University community. Some species enumerated showed signs of decay, disease and deformity. If these species were properly managed and maintained, they would have really exhibited their aesthetic values.

Conclusion: Trees have existed within the University of Lagos campus since its establishment; afforestation has also taken place due to aesthetic values and academic purpose. Overtime, lack of proper management caused trees to overgrow, while some are dying, thereby causing potential risk to both property and life within the University community. Repairs of these damage cost a lot; in view of these, proper tree management and maintenance options should be exercised to ensure sustainability of these trees and also mitigate future hazards.

\section{REFERENCES}

Adekanmbi, HO; Ogundipe, OT (2009). Mangrove Biodiversity, in the Restoration and sustainability of the Nigeria Natural Environment. J. Ecol. Nat. Environ. 3: 64-72.

Adekunle, VA; Olagoke, AO; Akindele, SO (2013). Tree species diversity and structure of a Nigerian strict nature reserve. Trop. Ecol. 54 (3): 275-289

Adeyemi, TO; Ogundipe, OT (2012). Biodiversity of Sapindaceae in West Africa. A checklist: International Inter. J. Biodiv. Conser. 4 (10): 358-363.
Alamu, L.O; Agbeja, BO (2011). Deforestation and endangered indigenous tree species in SouthWest Nigeria. Inter. J. Biodiv. Conser. 3 (7): 291-297.

Batta, H; Ashong, CA; Bashir, AS (2013). Press Coverage of Climate Change Issues in Nigeria and Implications for Public Participation Opportunities. J. Sustain. Develop. 6(2):56-62.

Food and Agriculture Organization (FAO) (2010). Forest products consumption study in Sudan. FAO Publication, Forest Handbooks for Genebanks, Kew Press, London. 152pp.

Ihenyen, J; Okoegwale. EE; Menshak, J (2009). Timber Resource status of Ehor Forest Reserve Uhunmwode Local Government Area of Edo State, Nigeria. Nat.Sci. 7(8):19-25.

Kabiru, Y (2008). Nigeria's Forest to disappear by 2020. African Conservation foundation. Network news report.

Kumar, A; Marcot, BG; Saxena, A (2006). Tree species diversity and distribution patterns in tropical forests of Garo hills. Current Scie. 91(10): 1370-1381

Ladipo, D (2010). The state of Nigeria's forests, IITA Research for Development Reviews (specials) 4. Retrieved from http://r4dreview.org/2010/04/the-state-ofnigeriasforests/

Nodza, GI; Onuminya, TO; Ogundipe, OT (2014). A checklist of tree species growing on akoka campus of the University of Lagos, Nigeria. Inter. J. Sci. Environ. Technol. 3 (3):1021-1034.

Pelemo, OJ; Akintola, BA; Temowo, OO; Akande, EO; Akoun, M (2011). Effects of Landscape Change on Biodiversity in Nigeria: Remote Sensing and GIS Approach. Continental. J. Environ. Design Manage. 1 (2): 22-29.

Shonubi, OO; Okusanya, OT (2007). Field study of Paspalum vaginatum S.W from the Mangrove swamp of Southwest. Inter. J. Bot. 4:366-372 